\title{
Value Stream Mapping of Rope Manufacturing: A Case Study
}

\author{
Korakot Yuvamitra, Jim Lee, and Kanjicai Dong \\ Systems Engineering Program, University of Louisiana at Lafayette, Lafayette, LA 70504, USA \\ Correspondence should be addressed to Jim Lee; jlee@louisiana.edu
}

Received 31 July 2016; Revised 28 November 2016; Accepted 19 December 2016; Published 16 February 2017

Academic Editor: Thomas R. Kurfess

Copyright (C) 2017 Korakot Yuvamitra et al. This is an open access article distributed under the Creative Commons Attribution License, which permits unrestricted use, distribution, and reproduction in any medium, provided the original work is properly cited.

\begin{abstract}
In today's competitive market place, manufacturing companies must apply continuous process improvement in order to maintain a returning customer base. One way of achieving constant process improvement is through value stream mapping. Value stream mapping is used to visualize the current processes for easier understanding and problem identification. A well-defined problem statement will ensure a successful outcome of a project improvement process. This research provides a case study performed on a rope manufacturing process. A current state value stream map is created, and the possible improvements are suggested. The implemented results are shown in the form of future state map. The results show that, after waste elimination and structural revision, a manufacturing process becomes more efficient, enabling the customer to receive an order significantly faster.
\end{abstract}

\section{Introduction}

In order to compete in the current markets, manufacturing companies need to review and continuously improve their manufacturing systems. The concept of Lean manufacturing [1] is to eliminate waste in the production that does not create value for the products or customers. The implementation of Lean requires management to grasp the current processes so that problems and opportunities for improvement can be identified. Poor implementation or partial vision of the situation may lead to an unsuccessful Lean journey.

The problem statement in this research of Lean manufacturing is for management to establish a visualized tool showing the current process of rope manufacturing. Steps for Lean implementation must be determined from a welldefined process map in order to estimate the improvement after implementation. In this situation, value stream mapping (VSM) is utilized as a Lean methodology to redesign manufacturing systems. The objective is to develop a VSM as a methodology for Lean implementation in the rope manufacturing industry. The methodology is carried out and examined in a case study of a 12 -strand rope production cell. In this case study, the problems are defined and a suggested solution is developed.

Lean manufacturing is one of the most well-known process development methodologies. It focuses on delivering value to the customer through the elimination of waste. Ideally, in manufacturing processes, products are supposed to be produced efficiently and with high quality and reliability. In reality, manufacturing processes always contain waste, which becomes the opportunity for process improvement [2]. Seven types of waste can be considered in a Lean manufacturing process. The types of waste are overproduction, waiting, unnecessary motion, extra processing, inventory, extra movement of employees and equipment, and defects [3]. While eliminating waste from a manufacturing process is an important step in Lean manufacturing, focusing only on waste elimination may cause the value flow to come to a halt since only one small part of the value stream is taken into consideration. Therefore, improvement goals should be applied to the whole flow.

The method VSM is used to visually represent the current and future states in the process of planning Lean. VSM represents the material and information flow of a process. Considered in the VSM are both value-added and nonvalue-added actions. Value-added activity is any action that increases the market form or function of the product or service. A non-value-added activity is any action which does not add market form or function or is not necessary [4].

VSM is divided into five phases. These phases are a selection of a product family, current state mapping, future state mapping, definition of a work plan, and achievement of 
the work plan [5]. By methodically applying the five phases to a process, all non-value-added activities can be identified and eliminated from the current process. The revised process will then be represented in the future state map. This future state map will offer a visual representation of the process with the non-value-added activities removed, resulting in shorter wait times and more efficient process flow. Due to the speed in which a VSM can identify waste in a process, it is an important first step toward achieving a Lean process [6].

The material and information flow in VSM helps visualize the overall manufacturing material flow instead of single or isolated operation, how operations currently communicate with production control and with each other, problem areas, waste sources, locate in-process inventory, and provide a common language for all manufacturing personnel [7]. Rother and Shook [5] affirm that the value stream is an essential tool for these reasons:

(i) VSM visualizes multiple processes, including the overall flow.

(ii) Waste and source of waste are identified.

(iii) VSM serves as a blueprint for Lean implementation.

(iv) VSM shows linkage between the information flow and material flow.

(v) VSM ties Lean concepts and techniques together.

(vi) VSM functions as both quantitative tools and qualitative tools.

The research performed by Serrano et al. [8, 9] shows that a value stream map developed within a Lean paradigm helped practitioners redesign production systems. These authors also state that other methodologies, methods, and tools are potentially applicable to the redesign of manufacturing systems. They are as follows:

(i) Process mapping or flow charts

(ii) Structured systems such as IDEFO (Icam DEFinition Zero) and SADT (Structured Analysis and Design Technique)

(iii) Architectural systems such as CIMOSA (Open System Architecture for CIM) and PERA (Purdue Enterprise Reference Architecture) (Williams 1998)

(iv) Modeling and simulation software

The conclusion reached in previous research indicates that the other methods do not fulfill the same framework, conditions, objectives, level, or degree of completion of manufacturing system design as the VSM. Although the material and information software seem to be promising in redesigning manufacturing systems, the software training cost and the amount of learning time needed negate a reasonable manufacturing process implementation.

\section{Case Study}

The methodology of VSM is developed based on the phases of application stated by Rother and Shook [5]. The first phase of this methodology is the selection of a product family. For this case study, the company selected was the manufacturer of Quantum 12 rope. Quantum 12 was selected because the process for production involves all the processes found in a rope manufacturing facility, while other types of ropes do not involve all processes. In other words, all machines and processes present in the manufacturing facility are used in the manufacture of Quantum 12 rope.

Quantum 12 is a light-weight, high-strength, floating rope that is preferred for its ability to grip on a capstan. The DPX yarn used in Quantum 12 provides superior abrasion and cut resistance as well as a higher coefficient of friction than similar high performance ropes. The added green Samthane coating provides excellent visibility and additional abrasion resistance. Quantum 12 rope has many applications including wire replacement, winch lines, offshore pick-up lines, and rig tow lines.

2.1. Current State Map. A current state map was created using information acquired for each process in the rope manufacturing. The current state map includes all steps in the process starting from receiving the customer order until the finished product is shipped. Data concerning operation time, material flow, information flow, and inventory were recorded. The current state map in Figure 1 has been further divided into two parts: (1) receiving order and (2) production processes. It is noted that various steps involved significant waiting time.

2.1.1. Receiving Order. A description of each activity involved in the information flow is identified and discussed below:

(1) Receiving customer order: customer service receives an order from the customer, processes order, and passes the order information to the initial production scheduler. The processing time is approximately 30 minutes.

(2) Initial production scheduling: the initial production scheduler waits 7 days to collect all orders received that week and makes a weekly production schedule and purchasing list. It takes approximately $120 \mathrm{~min}$ utes to process. The purchasing list is submitted to the purchasing department. The time it takes for the purchasing department to receive the purchasing list from customer service is 7 days.

(3) Delivery of raw materials: once the materials are purchased, it takes 14 days for the raw materials to be delivered from the supplier.

(4) Weekly production schedule: once the raw materials arrive, the rope supervisor creates the weekly production schedule. The processing time is approximately 2 hours. The raw material arriving this week will be put in process the following week.

(5) Shift scheduling: the rope supervisor assigns schedule to the shift supervisor. This process takes about 10 minutes.

(6) Assigning process work: the shift supervisor assigns work to the twisting, stranding, braiding, and splicing 


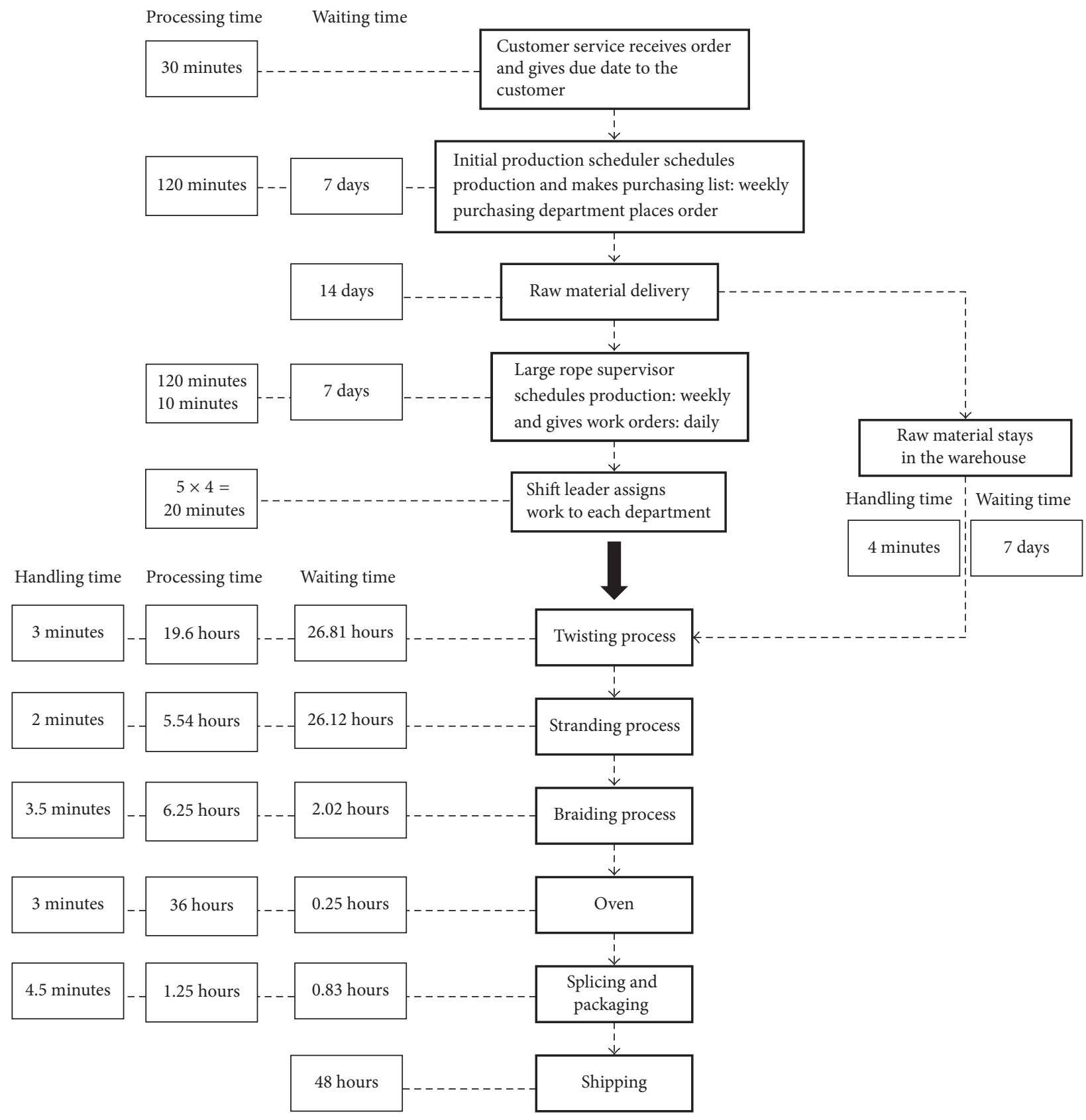

FIGURE 1: Current state map.

processes. The estimated time to assign each process is 5 minutes.

2.1.2. Production Processes. A description of each activity involved in the production flow is identified and discussed below:

(1) Setting up the twisting process: raw material (fiber) stays in the warehouse for 1 week before being used in the twisting process. It takes about 4 minutes to move all the material from the warehouse to the processing cell.
(2) Twisting process: the fiber is twisted into yarn. It takes almost 1 day to twist the fiber into yarn.

(3) The packages of yarn will be used in the stranding process.

(4) Braiding process: the strand is braided the day after it is made.

(5) Baking, splicing, and packaging processes: after rope is braided, it will be put in the oven, spliced, and packaged. 


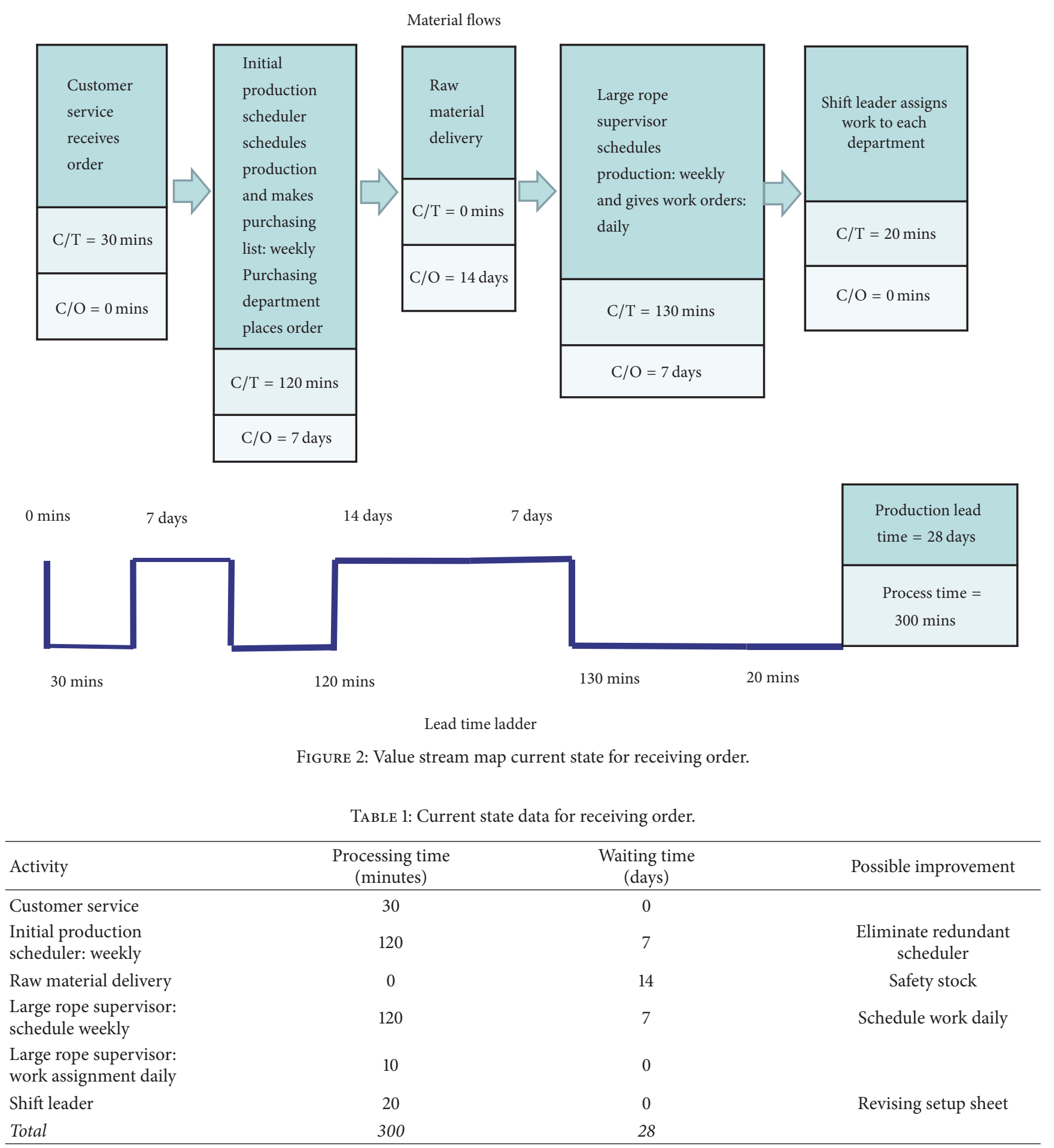

(6) Shipping: the packaged rope will be placed in a warehouse by the shipping department warehouse. The finished product stays in the warehouse about 2 days before being shipped to the customer.

Tables 1 and 2 summarize the numerical data of current value stream map for each of the two processes discussed above. A review of the process indicates that the receiving order part has a greater potential for saving. A VSM using standard notations for this part is shown in Figure 2.

2.2. Future State Map. A review of the current state map using Lean principles resulted in a number of modifications to the current process. The future state map including revisions to improve the process is shown in Figure 3. A VSM using standard notations for receiving order is shown in Figure 4. 


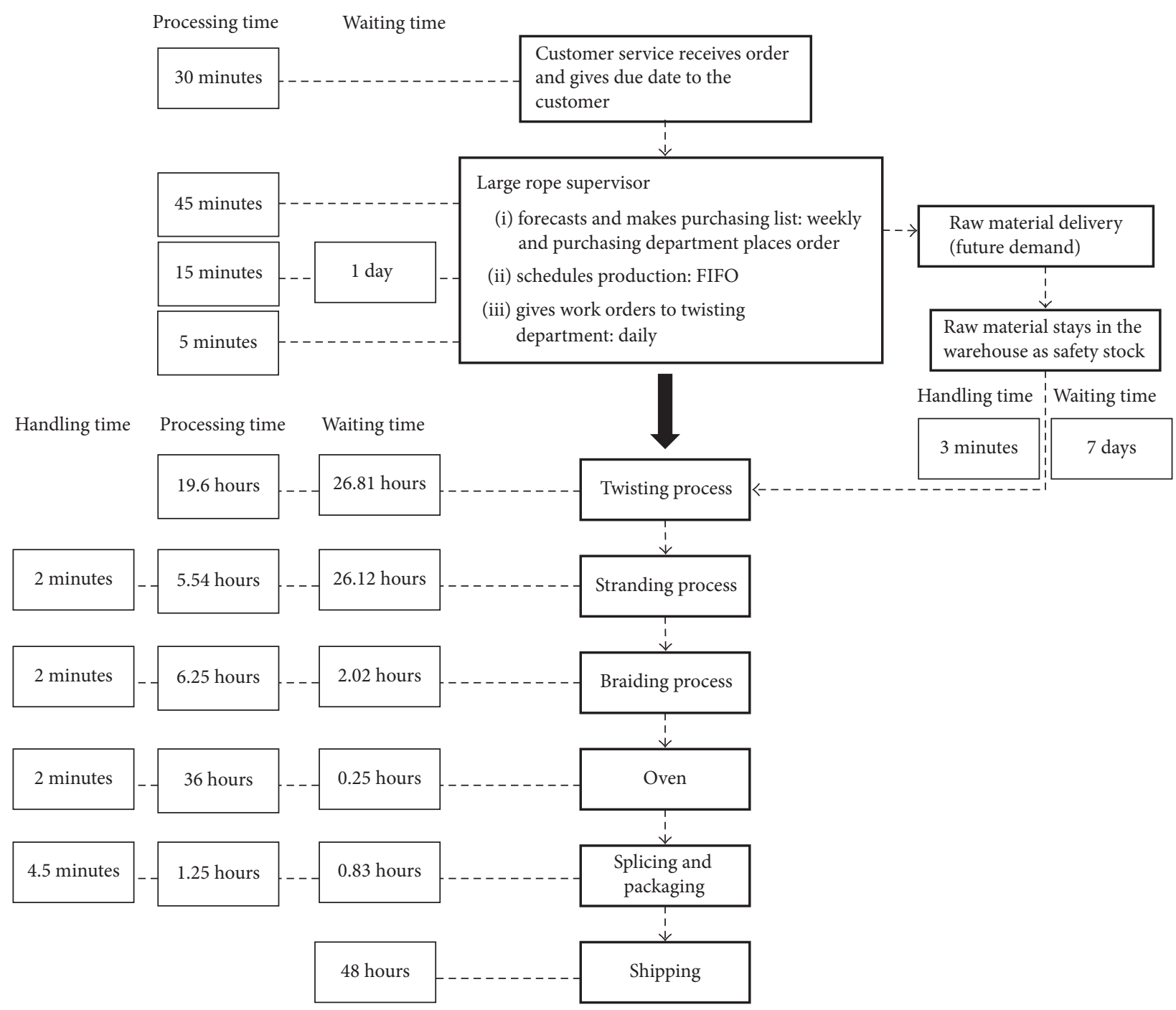

FIGURE 3: Future state map.

TABLE 2: Current state data for production processes.

\begin{tabular}{|c|c|c|c|c|}
\hline Department & $\begin{array}{l}\text { Processing time } \\
\text { (hours) }\end{array}$ & $\begin{array}{l}\text { Waiting time } \\
\text { and non-value- } \\
\text { added time } \\
\text { (hours) }\end{array}$ & $\begin{array}{l}\text { Material handling } \\
\text { time (minutes) }\end{array}$ & Possible improvement \\
\hline Warehouse & 0 & 168 & 4 & \\
\hline Twisting & 19.6 & 26.81 & 3 & \\
\hline Stranding & 5.5 & 26.12 & 2 & \\
\hline Braiding & 6.3 & 2.02 & 3.5 & Revise plant layout \\
\hline Oven & 36.0 & 0.25 & 3 & \\
\hline Splicing and packaging & 1.3 & 0.83 & 4.5 & \\
\hline Shipping & 0.0 & 48 & 0 & \\
\hline Total value-added time & \multicolumn{4}{|c|}{69 hours } \\
\hline Material handling time & \multicolumn{4}{|c|}{20 minutes } \\
\hline Production lead time & \multicolumn{4}{|c|}{8 days } \\
\hline Receiving order: shipping & \multicolumn{4}{|c|}{36 days } \\
\hline
\end{tabular}


Material flows
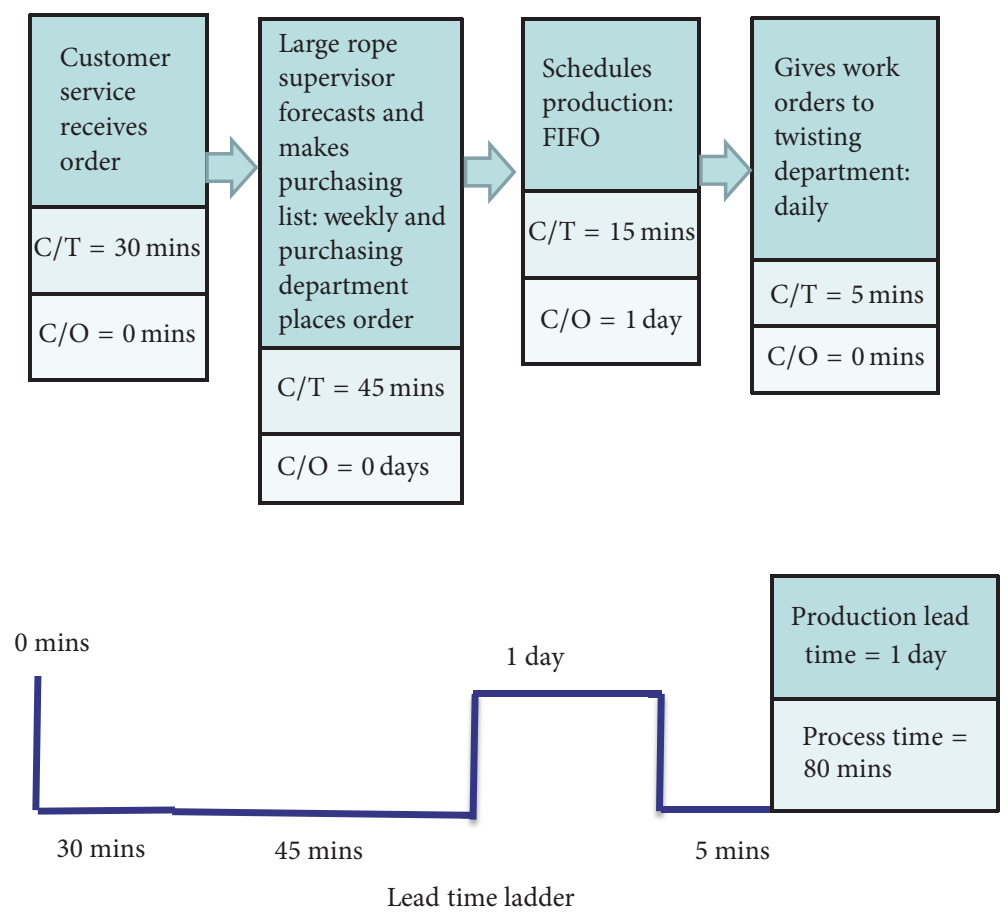

FIGURE 4: Value stream map future state for receiving order.

\begin{tabular}{|c|c|c|c|c|c|c|}
\hline \multirow{2}{*}{\multicolumn{7}{|c|}{ Q-12 }} \\
\hline & & & & & & \\
\hline \multirow{2}{*}{\multicolumn{7}{|c|}{$\begin{array}{l}\text { Date: 4/8/08 } \\
2^{\prime \prime} \text { dia O-12 }\end{array}$}} \\
\hline & $\mathrm{Q}-12$ & & & & & \\
\hline \multicolumn{7}{|c|}{ Q-12 } \\
\hline \multirow{2}{*}{\multicolumn{7}{|c|}{1 run $2000 \mathrm{ft} 1$ boobin from each tube }} \\
\hline \multicolumn{2}{|c|}{ Total footage } & 2000 & & & & \\
\hline $\begin{array}{l}\text { No } \\
\text { tubes }\end{array}$ & Footage & Type & Size & $\begin{array}{c}\text { Twist } \\
\text { Dir }\end{array}$ & tpf & Lbs/tube \\
\hline 20 & 14400 & SK75 & $2400 / 10+1600 / 1$ & $\mathrm{R} / \mathrm{L}$ & 6.5 & 27.53 \\
\hline 20 & 14400 & SK75 & $2400 / 10+1600 / 1$ & $\mathrm{~L} / \mathrm{L}$ & 6.5 & 27.53 \\
\hline $\begin{array}{l}\text { No } \\
\text { tubes }\end{array}$ & Footage & & Type/Size & $\begin{array}{c}\text { Twist } \\
\text { Dir }\end{array}$ & $\operatorname{tpf}$ & Lbs/tube \\
\hline & & & SLIVER 52 grain & & & \\
\hline 7 & 14400 & & $2400 / 10+1600 / 1$ & $\mathrm{R} / \mathrm{L}$ & 0 & 27.53 \\
\hline 7 & 14400 & 0 & $2400 / 10+1600 / 1$ & $\mathrm{~L} / \mathrm{L}$ & 0 & 27.53 \\
\hline
\end{tabular}

FIgURE 5: Setup sheet for twisting department-current state.

A description of the modifications is listed below.

(1) Safety Stock. The current state map (Figure 1) shows that production delay can be avoided by ordering the raw materials needed when customer places order. It takes about 2 weeks for raw material to be delivered. Having a week's worth of safety stock (since purchasing is done weekly) will eliminate 2 weeks of waiting time for the raw materials. Having a safety stock will allow raw material to be ready for use the same week an order is made, saving seven days by eliminating the need to schedule on a weekly basis. We have also considered inventory ranking methods suggested by Ben Hmida et al. [10] to focus on the key inventory items.

(2) Eliminating Redundant Scheduler. The initial scheduler performs a similar function as the rope supervisor. If the initial scheduler was removed, there would be a reduction of 7 days of waiting time. Changing the information structure, along with adding a safety stock, will also cut the time it takes in order to be put into production from 28 days to 1 day. The drawback of this change is that the rope supervisor will have to be in charge of making weekly purchasing list in 


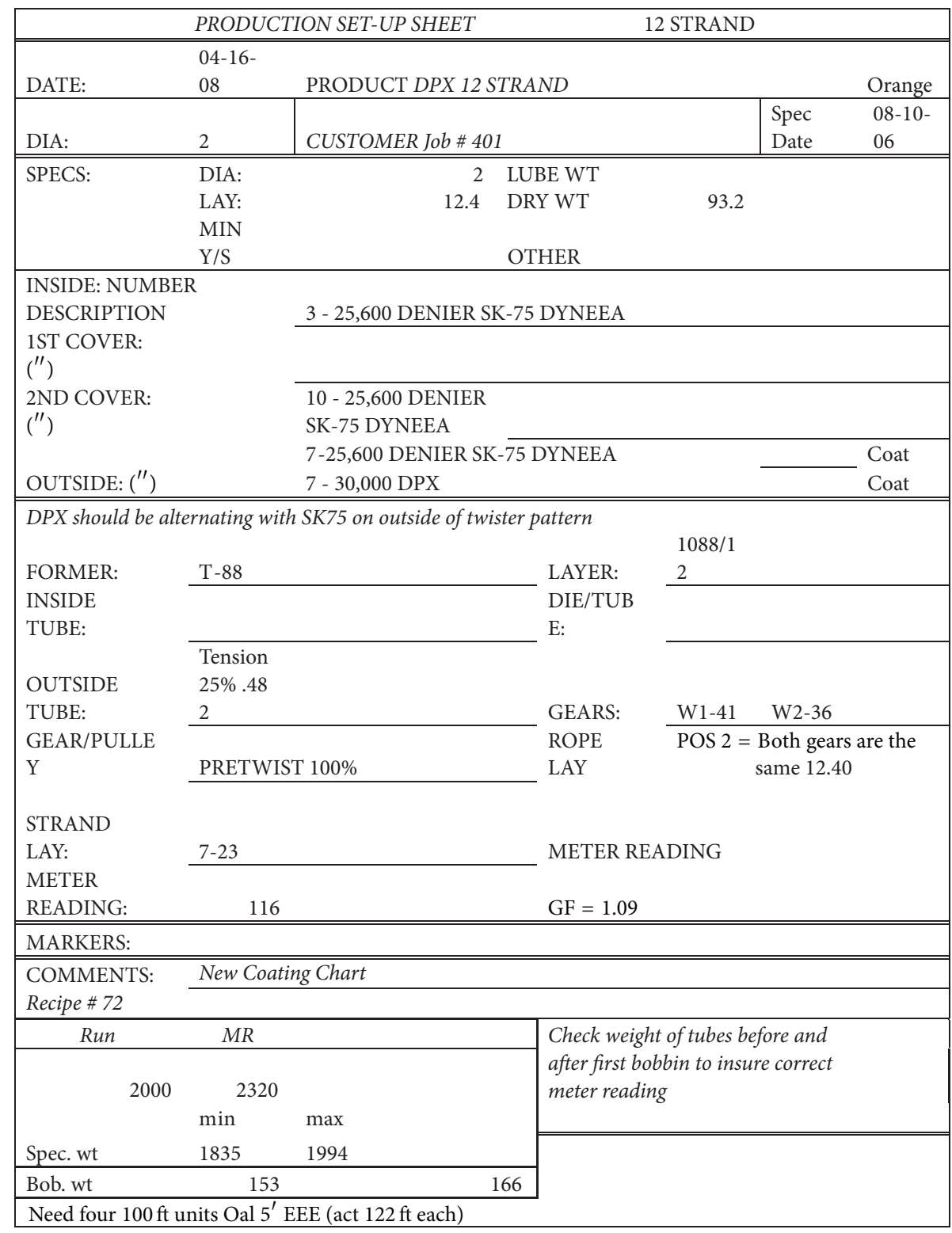

FIGURE 6: Setup sheet for stranding, braiding, and splicing—current state.

addition to previous responsibilities assigned in the current state. Scheduling systems such as Ben Hmida et al. [11] are also considered to improve our production scheduling.

(3) Revising Setup Sheet. The current state map (Figure 1) shows that the rope supervisor must assign work to the shift leader every day for 10 minutes. The shift leader then has to go to each department to assign work. The shift leader spends approximately 5 minutes in each department (twisting, stranding, braiding, and splicing) resulting in a total of 20 minutes. There is no work assigning time for the oven since the rope supervisor sets the machine.

By creating a setup sheet that contains all the information and notices needed by all departments, the shift leader eliminates the need to brief each department separately on their duties. The rope supervisor can assign duties directly to the twisting department, and all other departments downstream will receive the information on the setup sheet when it is passed to the next process with the finished product. This change can save up to 25 minutes every day. The current setup sheet for twisting department is shown in Figure 5 and for other departments in Figure 6. Figures 7 and 8 provide a revised setup sheet which contains all the information for all departments.

(4) Revising Plant Layout. Revising the plant layout can eliminate material handling time of the current state map (as shown in Figure 1 and Table 1). The current plant layout and the revised plant layout are shown in Figures 9 and 10.

The changes to the plant layout are as follows:

(1) The raw material has been moved from the current location in the corner of the warehouse to the 


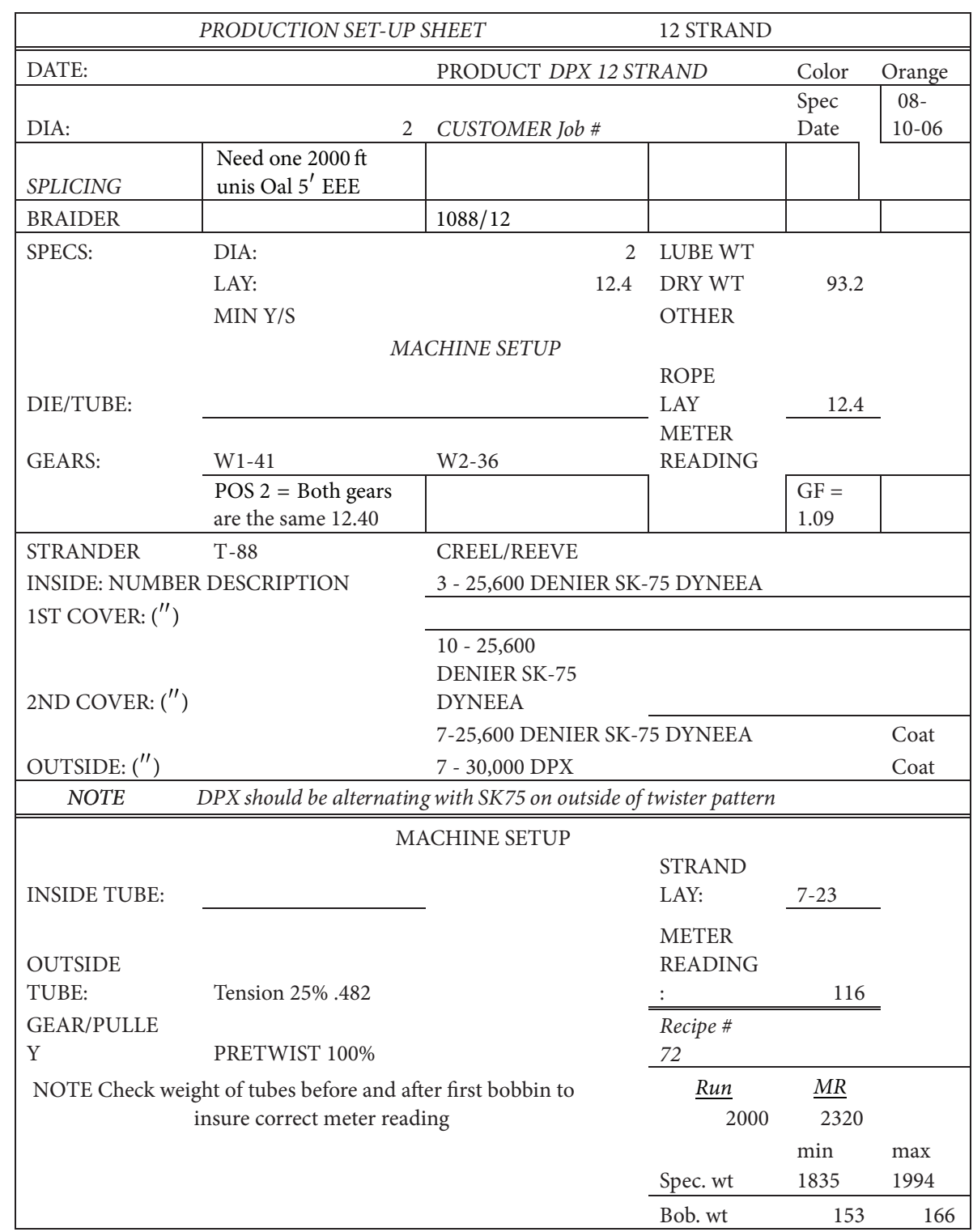

FIGURE 7: Setup sheet for all departments-future state.

\begin{tabular}{|c|c|c|c|c|c|c|c|c|}
\hline \multicolumn{9}{|c|}{ COMMENTS: New Coating Chart } \\
\hline \multicolumn{3}{|l|}{ TWWISTER } & \multicolumn{2}{|c|}{1 run $2000 \mathrm{ft} 1$ boobin from each tube } & \multicolumn{2}{|c|}{2000} & & \multirow[b]{2}{*}{ Lbs/tube } \\
\hline No tubes & & Footage & Type & Size & $\begin{array}{c}\text { Twist } \\
\text { Dir }\end{array}$ & tpf & & \\
\hline \multirow{5}{*}{ No tubes } & 20 & 14400 & SK75 & $2400 / 10+1600 / 1$ & $\mathrm{R} / \mathrm{L}$ & & 6.5 & 27.53 \\
\hline & 20 & 14400 & SK75 & $2400 / 10+1600 / 1$ & $\mathrm{~L} / \mathrm{L}$ & & 6.5 & 27.53 \\
\hline & & Footage & Type/Size & DENIER & $\begin{array}{l}\text { Twist } \\
\text { Dir }\end{array}$ & $\operatorname{tpf}$ & & \\
\hline & 7 & 14400 & $\begin{array}{l}\text { SLIVER } 52 \text { grain } \\
2400 / 10+1600 / 1\end{array}$ & 30000 & $\mathrm{R} / \mathrm{L}$ & & 0 & \\
\hline & 7 & 14400 & $\begin{array}{l}0 \\
2400 / 10+1600 / 1\end{array}$ & 30000 & $\mathrm{~L} / \mathrm{L}$ & & 0 & \\
\hline
\end{tabular}

FIGURE 8: Setup sheet comments section for all departments-future state. 


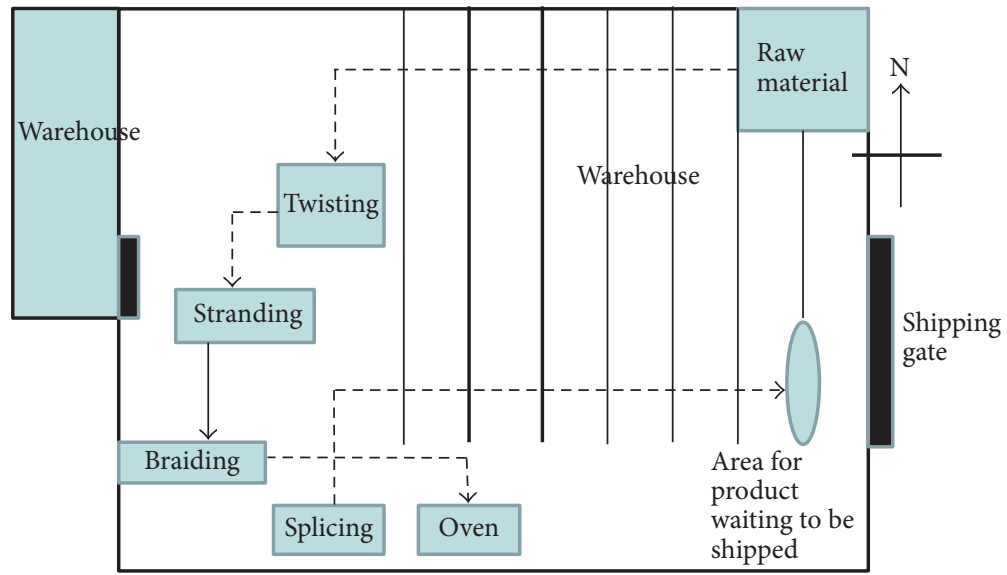

FIGURE 9: Current plant layout.

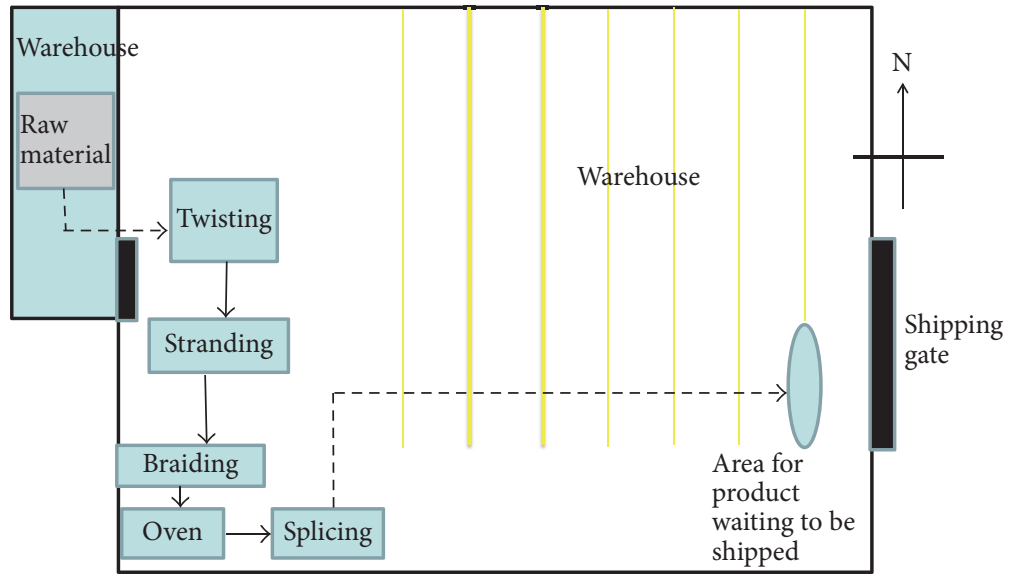

FIGURE 10: Revised plant layout.

warehouse on the west side. This modification moves the raw materials closer to the production machines.

(2) The twisting cell was moved closer to the warehouse and stranding cell. In the current plant layout, the basket of twisted yarn is delivered to the stranding cell by the forklift. In the revised layout, the twisting cell is closer to the stranding cell, and the stranding operator can take twisted yarn directly from the basket in the twisting area.

(3) The oven was moved to a location closer to the braiding and splicing cells for better process flow. The new location for the oven is close enough to the splicing machine that a forklift is used only to lift and move material without travelling any distance.

In each process, it takes approximately two minutes for the forklift or hoist to balance and secure material before moving. This time is fixed and will not be changed in the revised layout calculation. The travelling time varies by the travelling length of the forklift. Revised travelling time is calculated by the proportion of distance travelled in the current plant layout compared to the revised plant layout. The numerical data is shown in Tables 3 and 4 .
After the revisions were made to the plant layout, the current value stream map (Figure 1) is recalculated. The value stream map data of future state are shown in Tables 5 and 6.

\section{Performance Comparison}

The future state shows some changes after Lean implementation, and a performance comparison is shown in Table 7.

For the information flow, the processing time and waiting time are reduced by an estimated $68 \%$ and $88 \%$, respectively. For production processes, the material handling time is reduced by $33 \%$ due to revision of the plant layout. The total cycle time from receiving customer order to shipping is reduced from 36 days to 9 days. This is a reduction of $75 \%$ total time from the moment the customer places an order to the time it is shipped. Production lead time is the same.

\section{Conclusion}

Throughout this case study, Lean concepts have been implemented to the rope manufacturing process. The goal of these changes was to decrease the overall time required for the 
TABLE 3: Transfer time-current plant layout.

\begin{tabular}{lcc}
\hline Activity & Fixed time (minutes) & Traveling time (minutes) \\
\hline Forklift: delivering material from warehouse to twister & 2 & 2 \\
Forklift: delivering yarn to strander & 2 & 1 \\
Hoist: moving bobbin of yarn from strander to braider & 2 & 0 \\
Forklift: moving finished rope to oven & 2 & 1.5 \\
Forklift: moving finished rope to oven to splicing area & 2 & 1 \\
Forklift: moving finished rope from splicing area to shipping area & 2 & 2.5 \\
\hline
\end{tabular}

TABLE 4: Transfer time-revised plant layout.

\begin{tabular}{lcc}
\hline Activity & Fixed time (minutes) & Traveling time (minutes) \\
\hline Forklift: delivering material from warehouse to twister & 2 & 1 \\
Operator of strander uses yarn directly from the basket in that area & 0 & 0 \\
Hoist: moving bobbin of yarn from strander to braider & 2 & 0 \\
Forklift: moving finished rope to oven to splicing area & 2 & 0 \\
Forklift: moving finished rope from splicing area to shipping area & 2 & 2.5 \\
\hline
\end{tabular}

TABLE 5: Value stream map future state receiving order-putting work in process.

\begin{tabular}{lcc}
\hline Activities & Processing time (minutes) & Waiting time (days) \\
\hline Customer service & 30 & 0 \\
Large rope supervisor & 0 & 1 \\
Purchasing list weekly & 45 & 0 \\
Schedule daily FIFO & 15 & 0 \\
Work assignment daily & 5 & 0 \\
Total & 95 & 1 \\
\hline
\end{tabular}

TABLE 6: Value stream map future state production processes.

\begin{tabular}{lccc}
\hline Department & $\begin{array}{c}\text { Processing } \\
\text { time (hours) }\end{array}$ & $\begin{array}{c}\text { Waiting time and } \\
\text { non-value-added } \\
\text { time (hours) }\end{array}$ & $\begin{array}{c}\text { Material handling } \\
\text { time (minutes) }\end{array}$ \\
\hline Warehouse & 0 & 168 & 3 \\
Twisting & 19.6 & 26.81 & 0 \\
Stranding & 5.54 & 26.12 & 2 \\
Braiding & 6.25 & 2.02 & 2 \\
Oven & 36 & 0.25 & 4.5 \\
Splicing and packaging & 1.25 & 0.83 & 0 \\
Shipping & & 48 & 69 hours \\
Total value-added time & & 13.5 minutes \\
Material handling time & & 8 days \\
Production lead time & & 9 days \\
Receiving order/shipping & &
\end{tabular}

company to get the customer's order. Lean concepts were first applied to the information flow system. By changing the setup sheets for all departments, the processing time will be reduced by an estimated $68 \%$. Reducing the processing time will also have a dramatic effect on the waiting time for each order. Along with the setup sheet changes, implementing other Lean concepts such as the way daily work instructions are relayed to employees will also have dramatic effects on the total waiting time for each order received. With the new setup sheets, as well as having a safety stock ready for orders, the total waiting time of the process will be reduced by a staggering $88 \%$.

The material flow of the manufacturing process was considered in this case study. The case study shows that the floor layout can help to make the entire process more efficient. By changing the manufacturing floor setup to make 
TABLE 7: Value stream map data-performance comparison.

\begin{tabular}{lccc}
\hline & Current state & Future state & Percentage reduced \\
\hline Receiving order & & & 95 minutes \\
Processing time & 300 minutes & 1 day & $68 \%$ \\
Waiting time & 28 days & & $88 \%$ \\
Production processes & & 69 hours & $0 \%$ \\
Total value-added time & 69 hours & 13.5 minutes & $33 \%$ \\
Material handling time & 20 minutes & 8 days & $0 \%$ \\
Production lead time & 8 days & 9 & $75 \%$ \\
Receiving order: shipping & 36 & & \\
\hline
\end{tabular}

the material flow more well-organized, 6.5 minutes can be saved in material handling for each order. This is a total savings of $33 \%$ for material handling time. This case study also shows that having a safety stock of material will also reduce the waiting time for the process by estimated $88 \%$.

As previously stated, Lean manufacturing must account for all aspects of the production process in order to have a positive impact on the manufacturing process. This case study applied Lean changes to the information flow system, as well as the material flow system, to reduce the total time required from the time an order is received to the time the rope is shipped to the customer. Implementing changes in both the information flow system and the material flow system will save an estimated $75 \%$ for the manufacturing time of the rope. In other words, the suggested changes will reduce the time it takes to manufacture the rope and ship the order from 36 days to 9 total days.

\section{Competing Interests}

The authors declare that they have no competing interests.

\section{Acknowledgments}

This research is partially supported by Louisiana Department of Natural Resources (DNR) under Contract no. 2031-14-03.

\section{References}

[1] J. C. Green, J. Lee, and T. A. Kozman, "Managing lean manufacturing in material handling operations," International Journal of Production Research, vol. 48, no. 10, pp. 2975-2993, 2010.

[2] H. Lichtenberg, "Applying Lean principal in process industries," Industrial Maintenance \& Plant Operation, vol. 69, no. 6, pp. 2425, 2008.

[3] B. J. Hicks, "Lean information management: understanding and eliminating waste," International Journal of Information Management, vol. 27, no. 4, pp. 233-249, 2007.

[4] D. F. Garrett and J. Lee, "Lean construction submittal processa case study," Quality Engineering, vol. 23, no. 1, pp. 84-93, 2011.

[5] M. Rother and J. Shook, Learning to See: Value Stream Mapping to Create Value and Eliminate MUDA, The Lean Enterprise Institute, Brookline, Mass, USA, 1999.

[6] F. Garcia, "Using value stream mapping to develop improved facility layouts," in Proceedings of the IIE Annual Conference and Expo 2007-Industrial Engineering's Critical Role in a Flat World, Nashville, Tenn, USA, May 2007.

[7] D. Tapping, T. Luyster, and T. Shuker, Value Stream Management: Eight Steps to Planning, Mapping, and Sustaining Lean Improvements, Productivity Press, New York, NY, USA, 2002.

[8] I. Serrano, C. Ochoa, and R. De Castro, "Evaluation of value stream mapping in manufacturing system redesign," International Journal of Production Research, vol. 46, no. 16, pp. 44094430, 2008.

[9] I. Serrano, C. Ochoa, and R. D. Castro, "An evaluation of value stream mapping tool," Business Process Management Journal, vol. 13, no. 1, pp. 39-52, 2008.

[10] J. B. Hmida, S. Parekh, and J. Lee, "Integrated inventory ranking system for oilfield equipment industry," Journal of Industrial Engineering and Management, vol. 7, no. 1, pp. 115-136, 2014.

[11] J. Ben Hmida, J. Lee, X. Wang, and F. Boukadi, "Production scheduling for continuous manufacturing systems with quality constraints," Production \& Manufacturing Research, vol. 2, no. 1, pp. 95-111, 2014. 


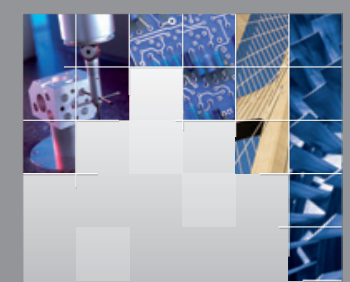

\section{Enfincering}
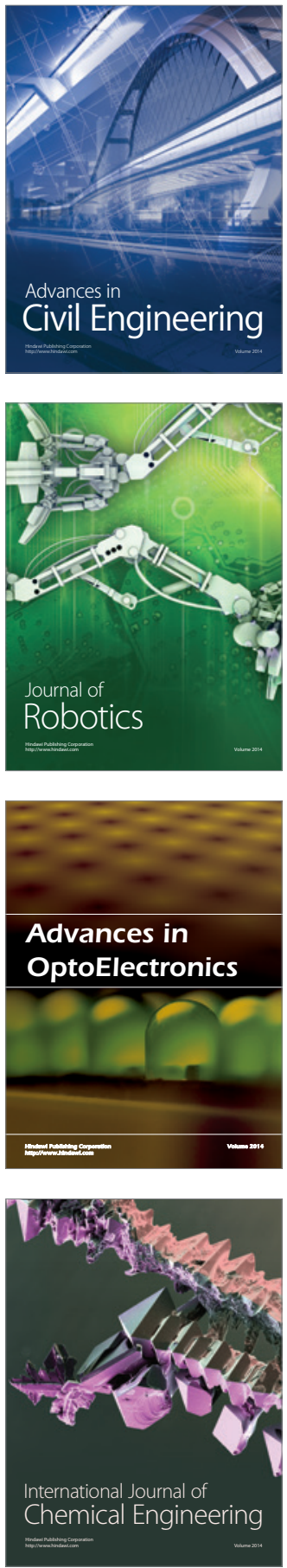

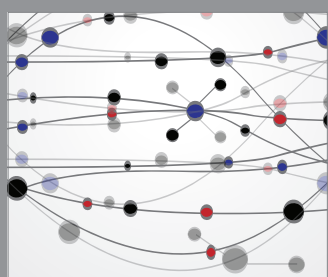

The Scientific World Journal

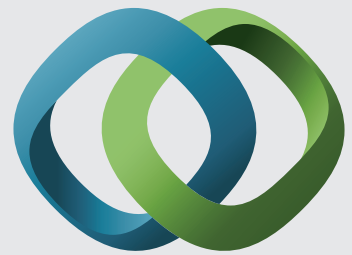

\section{Hindawi}

Submit your manuscripts at

https://www.hindawi.com
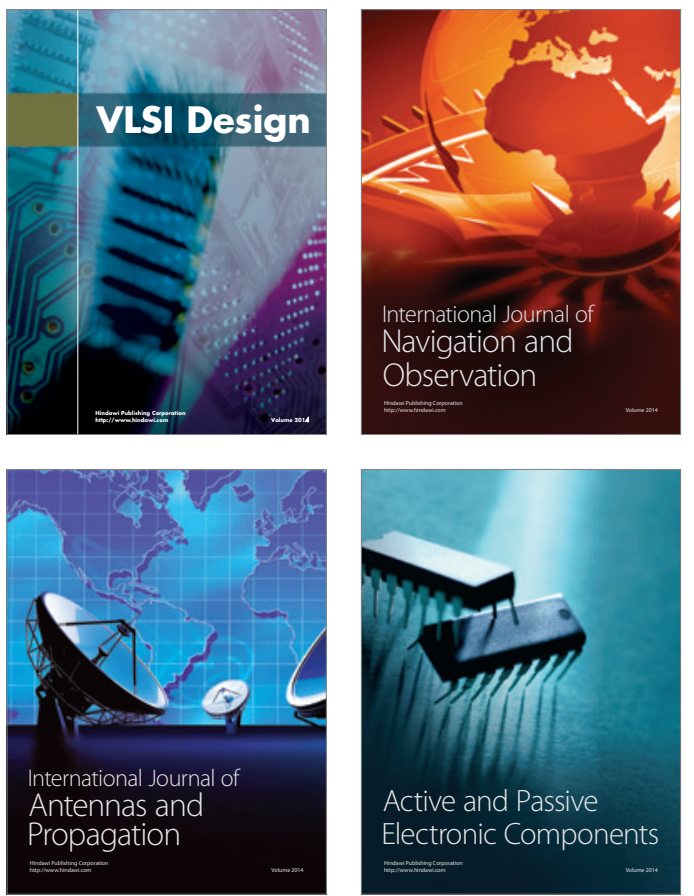
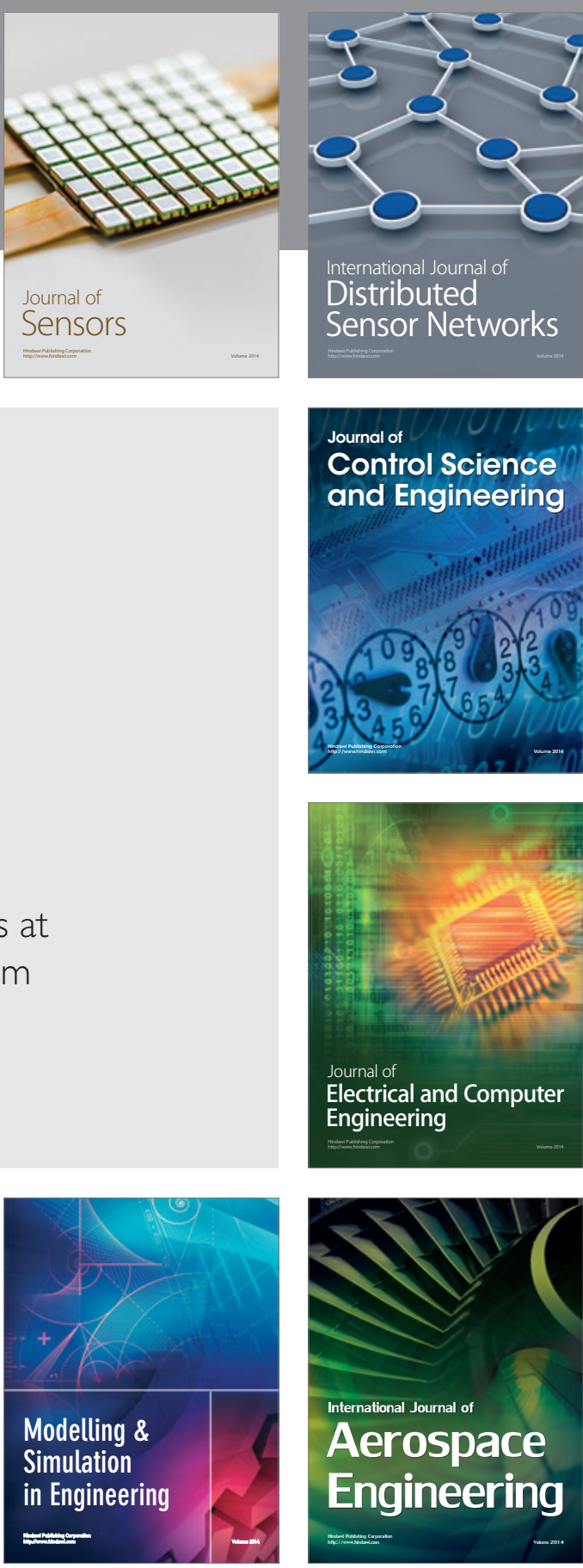

International Journal of

Distributed

Sensor Networks

$-$

Joumal of

Control Science

and Engineering
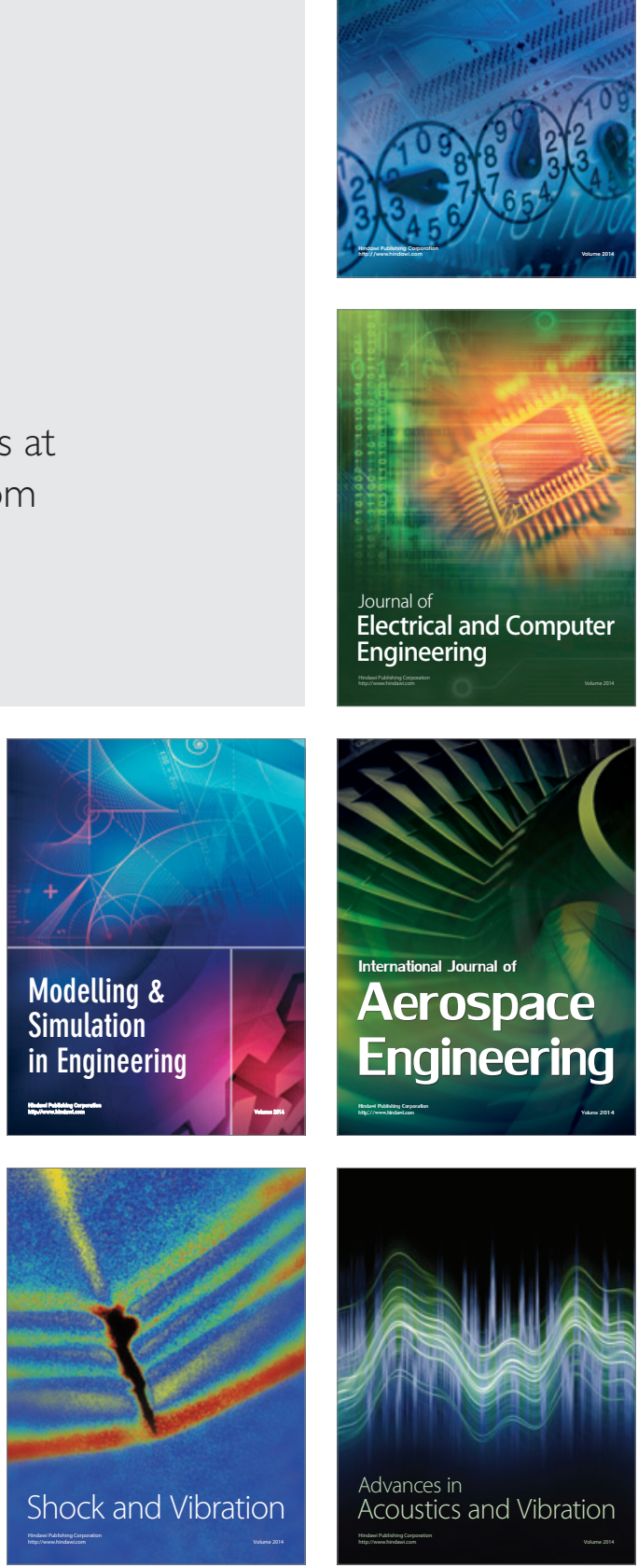